\title{
Comparison of Nesting Site Preferences and Breeding Ecology of Red- Vented Bulbul, Baya Weaver, and Grey Bush Chat in Sheikh Badin National Park Dera Ismail Khan, Pakistan
}

\author{
Inam Ullah ${ }^{1,2}$, WU Qing-Ming ${ }^{1 *}$, Ruqia Bibi ${ }^{2}$ and Najam Un Nisa ${ }^{2}$
}

${ }^{1}$ College of Wildlife and Protected Area, Northeast Forestry University, Harbin 150040, P. R. China; ${ }^{2}$ Department of Zoology, Government Girls College No. 2 Dera Ismail Khan, Pakistan.

\begin{abstract}
Nesting is a common phenomenon related to the birds' reproductive behavior. Nests play a pivotal role in various growth stages of birds, including breeding, defense, environmental factors, shelter, and conservation. The relation between a bird and plant species is considered to be the central aspect of wildlife and biodiversity, which makes the nesting behavior a vital factor when investigating the life of birds. This study was conducted to know the trees used for nesting by avifauna species of Sheikh Badin National Park. The current study was conducted at Sheikh Badin National Park from October 2018 to September 2019 Most birds' breeding was observed from May to August. The dominant tree and shrub species include Ziziphus jujuba, Ziziphus mauritiana, Acacia Nilotica, Cortaderia selloana, and Sheesham Olea oleaster. Thirty-nine (39) nests of 3 selected bird species, Red-vented bulbul (Pycnonotus cafer), Baya weaver (Ploceus philippinus), and Grey bush chat (Saxicola ferreus) were found in which 18 active nests were examined during the study period at different sampling sites. All the three birds' nest were observed on Acacia Nilotica. The average highest nests height of $5.06 \pm 0.43 \mathrm{~m}$ were observed for Red-vented bulbul. Maximum Nest $n=8$ of baya weaver bird observed. Grey Bush Chat successfully hatched 100\%. The average incubation days for Red-vented Bulbul $112.83 \pm 1.16$, Baya weaver $12.71 \pm 0.75$, and Grey bush chat $13.25 \pm 1.5$ were recorded.

Received | November 06, 2020; Accepted | December 14, 2020; Published | March 02, 2021

*Correspondence | WU Qing-Ming, College of Wildlife and Protected Area, Northeast Forestry University, Harbin 150040, P. R. China; Email: qingmingwu@126.com

Citation | Ullah, I., Qing-Ming, WU, Bibi, R. and Nisa, N.U., 2021. Comparison of nesting site preferences and breeding ecology of redvented bulbul, baya weaver, and grey bush chat in Sheikh Badin National Park Dera Ismail Khan, Pakistan. Journal of Innovative Sciences, 7(1): 40-48.

DOI | http://dx.doi.org/10.17582/journal.jis/2021/7.1.40.48

Keywords | Avifauna, Sheikh Badin, Incubation, Nest, Tree, Forest, Breeding, D.I. Khan, Pakistan
\end{abstract}

\section{Introduction}

$\mathrm{N}$ esting is a common phenomenon related to the birds' reproductive behavior. Nests play a pivotal role in various growth stages of birds, including breeding, defense, environmental factors, shelter, and conservation Tariq et al. (2018). Nests are crucial for bird's reproduction and are made for egg-laying and raise the young ones Steenhof and Newton (2007). Birds vary from one another in most of their life patterns such as distribution, food, plumage pattern, feet, beaks, habitat, colorations, and size; similarly, bird nests also have several differences in their construction pattern, site selection, the material used for nest building, shape, and size Vyas et al. (2009).

Nest sites are significant sources of bird fitness effects, influenced by many factors, such as the risk of nest predation, competition between species, and physiological tolerances to external factors MacArthur 
(1972), Diamond (1978), Connell (1975), Reitsma et al. (1999), Nalwanga et al. (2004) and Martin and Martin (2001). The selection of nest sites has an impact on offspring development and fitness Martin and Roper (1988). The section of an inappropriate site compromises both reproductive investment and parental survival Holway (1991). Hence, potential nesting sites provide protection against predators Gokula and Vijaya (2001), surplus and easy access to food Lenington (1980), Newton (1989), and shelter from harsh environmental conditions. Identification of essential factors involved in the nest-site selection is vital for employing the conservation methods for birds and their environment Pandey and Mohan (1993).

The nest size is correlated with the clutch size, nest type, and body size of a bird Slagsvold (1982, 1989a, b). Moreover, nest size and its insulation also vary along with both latitude and altitude Kern and Riper (1984). Birds'behavior of building nests has a strong association with pair formation and courtship.

Energy investments in reproduction are relatively easy to quantify by measuring egg mass, size, clutch size Lack (1968), Birchard and Deeming (2015). Investing large amounts of energy would increase the chance of survival of newborns, but this could be both time and resource-wise expansive Pilz et al. (2003). Therefore, a female has to balance clutch size according to the available energy resources Perrins (1996) and Krist (2011) and Lee and Lima (2017). Egg size can also vary within populations of the same species; in a smaller population, the egg size could be $50 \%$ larger than a larger population of the same species Randall et al. (2004).

The objectives of the present study were the comparison of vegetation used by Red-vented bulbul (Pycnonotus cafer), Baya weaver (Ploceus philippinus), and Grey bush chat (Saxicola ferreus) for nesting purpose and breeding ecology .

\section{Materials and Methods}

\subsection{Study area}

The present study was conducted in Sheikh Badin National Park (SBNP) Dera Ismail Khan District, Khyber Pakhtunkhwa, Pakistan $\left(32.297534^{\circ} \mathrm{N}\right.$, $70.805227^{\circ} \mathrm{E}$ ) (Figure 1). SBNP is situated in the middle of the Sheikh Badin Hills, an eastern extension of the Sulaiman Mountains. SBNP covers an area of 15,540 hectares with an elevation from 300 to 1350 MASL. The residential birds of SBNP are House crow, Chukor, House sparrow, See see, Red-vented Bulbul, Black and Grey partridge, Pigeon, Common myna, Doves, and Weaverbird.

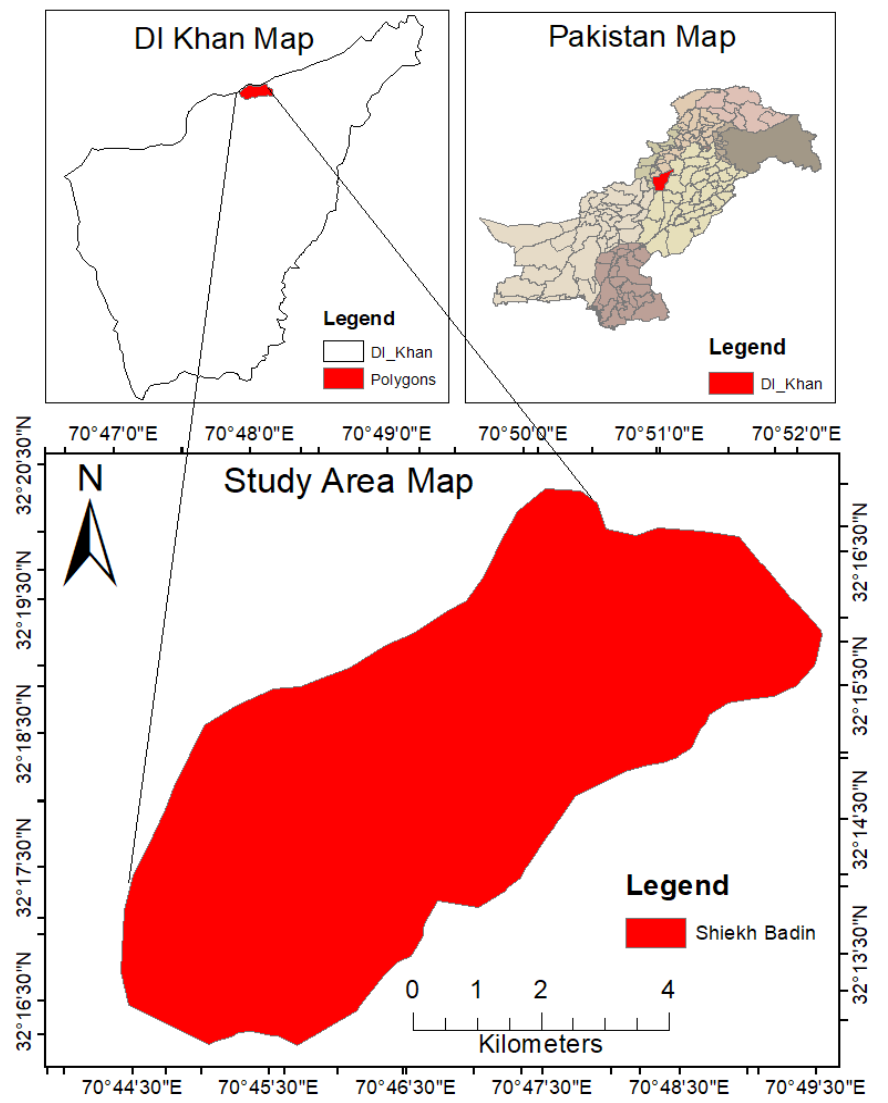

Figure 1: Location of the study area SBNP Dera Ismail Khan District, Khyber Pakhtunkhwa, Pakistan.

\subsection{Nest searching and monitoring}

The study was conducted from November 2018 to August 2019. From the middle of February (before breeding) to August (until no newly built nests were found). During this period, nest surveys were conducted every day by an experienced field assistant. Nests were found during the different developmental stages (nest-building, egg-laying, incubation, and nestling period). The following data were gathered: vegetation used for nesting, nest height from the ground level, nest diameter, cup diameter, nest characteristics, egg-laying date, clutch size, egg mass, egg volume, hatching size, incubation rhythm, hatching date, the number of hatchlings, fledging date, and the number of fledglings. If the nest was found during the egg-laying stage, clutch size was recorded by counting the number of eggs every day until no more eggs were laid. Nests found during 
the incubation period weren't included in the clutch size calculation because some eggs may have been lost before nest discovery. To decrease the risk of predation due to our visits, rubber gloves were worn when weighing the nestlings. The birds were observed through binocular (42X), and coordinates were taken using BENQ GPS. The nests of studied birds were found, identified, and photographed using the Nikon D7200 Sigma 150-600 mm lens. The height of the tree and nest was measured using Clinometer. Nests were observed through regular visits to gather all the data related to breeding stages. Trapping cameras (LTL-6210 6310) were installed carefully on the nest to record the size of the clutch, incubation time, hatching, and breeding success. The egg length and width were measured using a Vernier-caliper and weight through a digital weigh scale. The egg volume was measured through the formula (Donald,1979):

\section{$V=0.509 \times L \times B^{2} / 1000$}

\section{L=Length; B=Width/ Breadth}

Mean \pm standard error was applied for calculating the different parameters like tree height, Nest height, nest diameter, Egg size, egg weight, egg volume, nesting period, incubation period, clutch size.

\section{Results and Discussion}

A total of thirty-nine (39) nests of 3 selected bird species were founded, from which 18 active nests were examined at sampling points in the study region (Figure 1). All three species, Red-vented Bulbul, Baya weaver, and Grey bush chat, belong to the order Passeriformes. The highest numbers of nests $(n=8)$ were observed for Baya weaver (Ploceus philippinus) (Table 1), followed by Red-vented bulbul (Pycnonotus cafer) $n=6$ (Table 3) and Grey bush chat (Saxicola ferreus) $n=4$ (Table 5).

\subsection{Birds nesting and breeding ecology}

Red-vented bulbul: From the selected study area six nests of Red-vented bulbul were recorded (Table 1). The preferred tree species for nesting of Red-vented bulbul were Ziziphus mauritiana, Ziziphus jujube, and Acacia Nilotica. The Average Nest height $5.06 \pm$ $0.43 \mathrm{~m}$, mean nest diameter measured $24.28 \pm 1.48 \mathrm{~cm}$, Cup Diameter $13.05 \pm 0.4 \mathrm{~cm}$, and Cup Depth $\mathrm{cm}$ $10.01 \pm 0.27$. Nest Shape was Round and constructed from Dead leaves, twigs, rootlets, and dry grasses. The average Clutch Size (Eggs) was 2.83 \pm 0.75 , egg weight $5.42 \pm 0.37 \mathrm{~g}$, Length of Egg $19.77 \pm 1.15 \mathrm{~mm}$, Width of Egg 15.16 \pm 2.64 , Volume of Egg $2.4 \pm 0.6 \mathrm{~cm}^{3}$, and Incubation Period (Days) 12.83 \pm 1.16 . Hatching Success $95.83 \%$ and Fledging Success $91.66 \%$ was also recorded. The color of the eggs of Red-vented bulbul was pale pink with clear large, irregular red-brown marks (Table 2, Figure 2A).
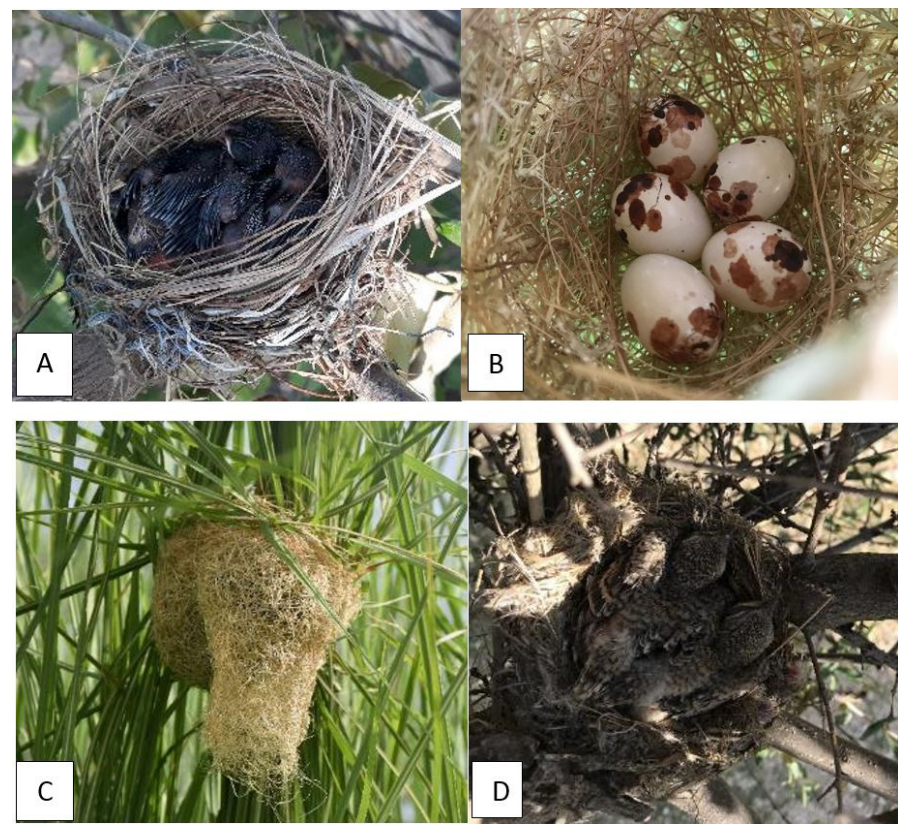

Figure 2: (A) Round structure nest of Red vented bulbul; (B) Baya weaver eggs in nest; (C) Pendulum Shape structure of Baya Weaver bird; (D) Nest of Grey Bush chat on wild olive.

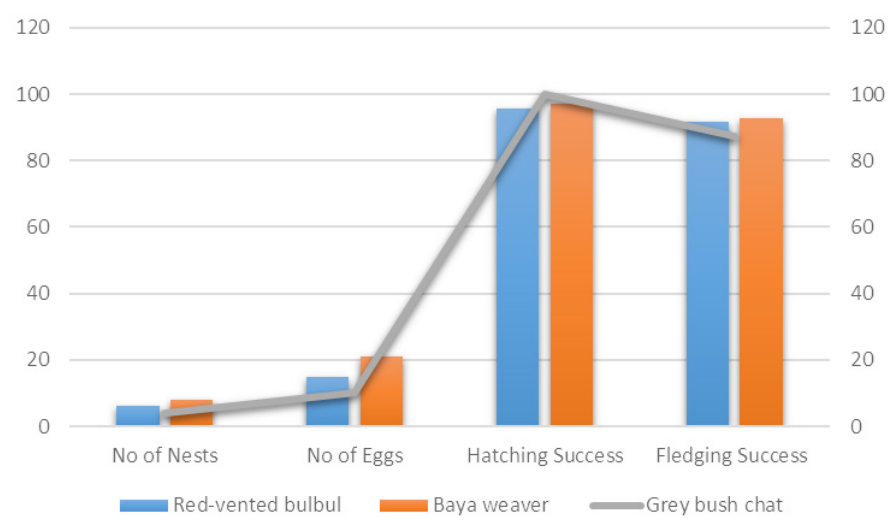

Figure 3: The total number of nest, egg, hatching success and Fledging success of selected bird species.

\subsection{Baya weaver}

From the selected study area eight nests of Baya weaver were recorded (Table 3); the preferred tree species for nesting included Cortaderia selloana, Acacia Niloticaand Ziziphus mauritiana. The Average Nest height $4.65 \pm 1.45 \mathrm{~m}$, mean nest diameter measured 
$16.05 \pm 0.92 \mathrm{~cm}$, Cup Diameter $8.45 \pm 0.66 \mathrm{~cm}$, and Width of Egg $9.39 \pm 0.85$, Volume of Egg $1 \pm 0 \mathrm{~cm}^{3}$, Cup Depth $\mathrm{cm} 10.73 \pm 1.24$. The nest was Pendulum Shape and constructed from Twigs, rootlets, and grasses. The average Clutch Size (Eggs) was $3 \pm 1$, egg and Incubation Period (Days) $12.71 \pm 0.75$. Hatching Success $97.14 \%$ and Fledging Success $92.85 \%$ was weight $4.65 \pm 0.43 \mathrm{~g}$, Length of Egg13.64 $\pm 0.83 \mathrm{~mm}$, also recorded. The color of the Baya weaver was Pale cream with dotes. (Table 4, Figure 2B, C).

Table 1: Nest site preferences and Nest characteristics of red-vented bulbul at Sheikh Badin National Park.

\begin{tabular}{llllllll}
\hline $\begin{array}{l}\text { No. } \\
\text { Vesetation used for }\end{array}$ & $\begin{array}{l}\text { Height of } \\
\text { nest }(\mathbf{m})\end{array}$ & $\begin{array}{l}\text { Nest diame- } \\
\text { ter }(\mathbf{c m})\end{array}$ & $\begin{array}{l}\text { Cup diame- } \\
\text { ter }(\mathbf{c m})\end{array}$ & $\begin{array}{l}\text { Cup depth } \\
(\mathbf{c m})\end{array}$ & $\begin{array}{l}\text { Nest } \\
\text { shape }\end{array}$ & Nest composition \\
\hline 1 & Ziziphus jujuba & 5.3 & 24.5 & 13.1 & 10.4 & Round & Dead leaves, twigs, rootlets, grasses \\
2 & Ziziphus jujuba & 4.7 & 21.6 & 12.8 & 9.7 & Round & \\
3 & Acacia nilotica & 5.7 & 23.9 & 13.4 & 10.2 & Round & \\
4 & Acacia nilotica & 4.8 & 25 & 12.9 & 10 & Round & \\
5 & Acacia nilotica & 5.3 & 24.7 & 12.5 & 9.7 & Round & \\
6 & Ziziphus mauritiana & 4.6 & 26 & 13.6 & 10.1 & Round & \\
& & $5.06 \pm 0.43$ & $24.28 \pm 1.48$ & $13.05 \pm 0.4$ & $10.01 \pm 0.27$ & & \\
\hline
\end{tabular}

Table 2: Egg and breeding ecology s of red-vented bulbul at Sheikh Badin National Park.

\begin{tabular}{|c|c|c|c|c|c|c|c|c|c|}
\hline $\begin{array}{l}\text { Nest } \\
\text { No. }\end{array}$ & $\begin{array}{l}\text { Clutch size } \\
\text { (Eggs) }\end{array}$ & $\begin{array}{l}\text { Weight of } \\
\text { egg (g) }\end{array}$ & $\begin{array}{l}\text { Length of } \\
\text { egg }(\mathrm{mm})\end{array}$ & $\begin{array}{l}\text { Width of } \\
\text { egg }(\mathrm{mm})\end{array}$ & $\begin{array}{l}\text { The volume of } \\
\text { egg }(\mathrm{cm} 3)\end{array}$ & Color of egg & $\begin{array}{l}\text { Incubation } \\
\text { period (Days) }\end{array}$ & $\begin{array}{l}\text { Hatching } \\
\text { success }\end{array}$ & $\begin{array}{l}\text { Fledging } \\
\text { success }(\%)\end{array}$ \\
\hline \multirow[t]{2}{*}{1} & \multirow[t]{2}{*}{2} & 5.3 & 20.3 & 15 & 2.3249 & \multirow{2}{*}{$\begin{array}{l}\text { Pink and pale } \\
\text { cream }\end{array}$} & \multirow[t]{2}{*}{13} & \multirow[t]{2}{*}{100} & \multirow[t]{2}{*}{100} \\
\hline & & 6.2 & 20.4 & 17.5 & 3.18 & & & & \\
\hline \multirow[t]{4}{*}{2} & \multirow[t]{4}{*}{4} & 5.7 & 20 & 16.2 & 2.6716 & \multirow{4}{*}{$\begin{array}{l}\text { Pink and pale } \\
\text { cream }\end{array}$} & \multirow[t]{4}{*}{14} & \multirow[t]{4}{*}{75} & \multirow[t]{4}{*}{100} \\
\hline & & 5.2 & 20.29 & 5.8 & 0.3474 & & & & \\
\hline & & 5.5 & 18.9 & 15.3 & 2.252 & & & & \\
\hline & & 4.9 & 17.7 & 14.7 & 1.9468 & & & & \\
\hline \multirow[t]{3}{*}{3} & \multirow[t]{3}{*}{3} & 5.3 & 21.1 & 15.1 & 2.4488 & \multirow{3}{*}{$\begin{array}{l}\text { Pink and pale } \\
\text { cream }\end{array}$} & \multirow[t]{3}{*}{14} & \multirow[t]{3}{*}{100} & \multirow[t]{3}{*}{100} \\
\hline & & 5.2 & 19.2 & 15.7 & 2.4089 & & & & \\
\hline & & 5.1 & 19.5 & 15.3 & 2.3235 & & & & \\
\hline \multirow[t]{3}{*}{4} & \multirow[t]{3}{*}{3} & 5.5 & 20.2 & 16 & 2.6321 & \multirow{3}{*}{$\begin{array}{l}\text { Pink and pale } \\
\text { cream }\end{array}$} & \multirow[t]{3}{*}{11} & \multirow[t]{3}{*}{100} & \multirow[t]{3}{*}{100} \\
\hline & & 6.1 & 21.8 & 16.4 & 2.9844 & & & & \\
\hline & & 5.8 & 18.7 & 16.5 & 2.5914 & & & & \\
\hline \multirow[t]{2}{*}{5} & \multirow[t]{2}{*}{2} & 5.6 & 19 & 17.1 & 2.8279 & \multirow{2}{*}{$\begin{array}{l}\text { Pink and pale } \\
\text { cream }\end{array}$} & \multirow[t]{2}{*}{12} & \multirow[t]{2}{*}{100} & \multirow[t]{2}{*}{50} \\
\hline & & 5.3 & 18.9 & 15.6 & 2.3411 & & & & \\
\hline \multirow[t]{4}{*}{6} & \multirow[t]{3}{*}{3} & 5.6 & 21.2 & 16.3 & 2.867 & \multirow{3}{*}{$\begin{array}{l}\text { Pink and pale } \\
\text { cream }\end{array}$} & \multirow[t]{3}{*}{13} & \multirow[t]{3}{*}{100} & 100 \\
\hline & & 5.1 & 20.9 & 14.7 & 2.2988 & & & & \\
\hline & & 4.9 & 18 & 14.2 & 1.8474 & & & & \\
\hline & $2.83 \pm 0.75$ & $5.42 \pm 0.37$ & $19.77 \pm 1.15$ & $15.16 \pm 2.64$ & $2.37 \pm 0.6$ & & $12.83 \pm 1.16$ & $95.83 \%$ & $91.66 \%$ \\
\hline
\end{tabular}

Table 3: Nest site preferences and nest characteristics of Baya weaver at Sheikh Badin National Park.

\begin{tabular}{llllllll}
\hline $\begin{array}{l}\text { No. Vegetation used for } \\
\text { nesting }\end{array}$ & $\begin{array}{l}\text { Height of } \\
\text { nest }(\mathbf{m})\end{array}$ & $\begin{array}{l}\text { Nest diame- } \\
\text { ter }(\mathbf{c m})\end{array}$ & $\begin{array}{l}\text { Cup diame- } \\
\text { ter }(\mathbf{c m})\end{array}$ & $\begin{array}{l}\text { Cup depth } \\
(\mathbf{c m})\end{array}$ & Nest shape & Nest composition \\
\hline 1 & Cortaderia selloana & 2.8 & 16.7 & 9.3 & 12.3 & Pendulum shape & Twigs, rootlets, and grasses \\
2 & Cortaderia selloana & 3.1 & 17.3 & 8.1 & 11.7 & Pendulum shape & Twigs, rootlets and grasses \\
3 & Acacia nilotica & 6.6 & 15.4 & 7.9 & 9.9 & Pendulum shape & Twigs, rootlets and grasses \\
4 & Acacia nilotica & 5.2 & 16.3 & 7.4 & 10.4 & Pendulum shape & Twigs, rootlets and grasses \\
5 & Acacia nilotica & 6.1 & 17 & 8.6 & 11.2 & Pendulum shape & Twigs, rootlets and grasses \\
6 & Acacia nilotica & 4.7 & 15.8 & 9.1 & 9.5 & Pendulum shape & Twigs, rootlets and grasses \\
7 & Cortaderia selloana & 3.21 & 14.7 & 9 & 8.9 & Pendulum shape & Twigs, rootlets and grasses \\
8 & Ziziphus mauritiana & 5.5 & 15.2 & 8.2 & 12 & Pendulum shape & Twigs, rootlets and grasses \\
& & $4.65 \pm 1.45$ & $16.05 \pm 0.92$ & $8.45 \pm 0.66$ & $10.73 \pm 1.24$ & & \\
\hline
\end{tabular}

Journal of Innovative Sciences

June 2021 | Volume 7| Issue 1 | Page 43 
3.3 Grey bush chat

Four nests of Grey bush chat (Saxicola ferreus) were recorded the selected study area (Table 5). The selected tree species for nesting of Grey bush chat were Acacia Nilotica and Olea oleaster. The Average Nest height $5.3 \pm 0.16 \mathrm{~m}$, mean nest diameter measured $24.87 \pm 1.33 \mathrm{~cm}$, Cup Diameter $13.3 \pm 0.48 \mathrm{~cm}$ and Cup Depth $\mathrm{cm} 10.17 \pm 0.29$. Nest was Round in shape and constructed from dead leaves, twigs, rootlets, grasses. The average Clutch Size (Eggs) was 2.5 \pm 0.57 , egg weight $5.44 \pm 0.38 \mathrm{~g}$, Length of Egg $19.99 \pm 1.0 \mathrm{~mm}$, Width of Egg 15.74 \pm 1.05 , Volume of Egg 2.53 \pm 0.37 $\mathrm{cm}^{3}$ and Incubation Period (Days) 13.25 \pm 1.5 . Hatching Success 100\% \% and Fledging Success
$87.5 \%$ was also recorded. The color of the Grey bush chat was Turkish blue with black dotes (Table 6, Figure 2D).

Several aspects are taken into account when a bird establishes a nest; among them, the most imperative one is minimizing the risk of predation. Birds caring for their chicks are most vulnerable to possible predation during the breeding season, which might affect their offsprings directly or indirectly (Martin and Martin, 2001; Quinn et al., 2003). Nest predation promotes nest destruction in a number of species (Lima, 2009), and so many bird species prefer thick vegetation cover for nest building and

Table 4: Egg and breeding ecology s of Baya weaver at Sheikh Badin National Park.

\begin{tabular}{|c|c|c|c|c|c|c|c|c|c|}
\hline $\begin{array}{l}\text { Nest } \\
\text { No. } \\
\end{array}$ & $\begin{array}{l}\text { Clutch } \\
\text { size (Eggs) }\end{array}$ & $\begin{array}{l}\text { Weight of } \\
\text { egg (g) }\end{array}$ & $\begin{array}{l}\text { Length of } \\
\text { egg }(\mathrm{mm})\end{array}$ & $\begin{array}{l}\text { Width of } \\
\text { egg }(\mathrm{mm})\end{array}$ & $\begin{array}{l}\text { Volume of } \\
\text { egg }(\mathrm{cm} 3)\end{array}$ & Color of egg & $\begin{array}{l}\begin{array}{l}\text { Incubation } \\
\text { period (Days) }\end{array} \\
\end{array}$ & $\begin{array}{l}\text { Hatching } \\
\text { success }\end{array}$ & $\begin{array}{l}\text { Fledging } \\
\text { success (\%) }\end{array}$ \\
\hline \multirow[t]{2}{*}{1} & 2 & 4.1 & 13.6 & 8.2 & 0.5 & Pale cream with dotes & 12 & 100 & 100 \\
\hline & & 4.7 & 12.1 & 7.6 & 0.4 & & & & \\
\hline \multirow[t]{3}{*}{3} & 3 & 4.9 & 13.6 & 8.9 & 0.5 & Pale cream with dotes & 13 & 100 & 100 \\
\hline & & 5.1 & 11.9 & 9.2 & 0.5 & & & & \\
\hline & & 4.4 & 13.8 & 10.2 & 0.7 & & & & \\
\hline \multirow[t]{3}{*}{4} & 3 & 3.9 & 14.9 & 11.1 & 0.9 & Pale cream with dotes & 14 & 100 & 100 \\
\hline & & 5.1 & 13.6 & 8.5 & 0.5 & & & & \\
\hline & & 4.6 & 13.1 & 9.4 & 0.6 & & & & \\
\hline \multirow[t]{2}{*}{5} & 2 & 3.8 & 12.8 & 10.5 & 0.7 & Pale cream with dotes & 12 & 100 & 50 \\
\hline & & 4.7 & 13.2 & 9.2 & 0.6 & & & & \\
\hline \multirow[t]{3}{*}{6} & 3 & 4.3 & 13.7 & 9.6 & 0.6 & Light cream & 13 & 100 & 100 \\
\hline & & 5.3 & 12.9 & 10.1 & 0.7 & & & & \\
\hline & & 4.7 & 13.6 & 8.4 & 0.5 & & & & \\
\hline \multirow[t]{3}{*}{7} & 3 & 4.9 & 15.1 & 9.1 & 0.6 & Light cream & 12 & 100 & 100 \\
\hline & & 5.1 & 14.3 & 9.6 & 0.7 & & & & \\
\hline & & 5.03 & 13.5 & 9.8 & 0.7 & & & & \\
\hline \multirow[t]{6}{*}{8} & 5 & 4.7 & 14.1 & 10.2 & 0.7 & Pale cream with dotes & 13 & 80 & 100 \\
\hline & & 4.2 & 13.9 & 8.5 & 0.5 & & & & \\
\hline & & 5.2 & 14.3 & 9.3 & 0.6 & & & & \\
\hline & & 4.3 & 15 & 10.2 & 0.8 & & & & \\
\hline & & 4.7 & 13.6 & 9.6 & 0.6 & & & & \\
\hline & $3 \pm 1$ & $4.65 \pm 0.43$ & $13.64 \pm 0.83$ & $9.39 \pm 0.85$ & $1 \pm 0$ & & $12.71 \pm 0.75$ & $97.14 \%$ & $92.85 \%$ \\
\hline
\end{tabular}

Table 5: Nest site preferences and Nest characteristics of Grey bush chat Sheikh Badin National Park.

\begin{tabular}{llllllll}
\hline No. & $\begin{array}{l}\text { Vegetation used } \\
\text { for nesting }\end{array}$ & $\begin{array}{l}\text { Height of } \\
\text { nest }(\mathbf{m})\end{array}$ & $\begin{array}{l}\text { Nest diame- } \\
\text { ter }(\mathbf{c m})\end{array}$ & $\begin{array}{l}\text { Cup diame- } \\
\text { ter }(\mathbf{c m})\end{array}$ & $\begin{array}{l}\text { Cup depth } \\
(\mathbf{c m})\end{array}$ & $\begin{array}{l}\text { Nest } \\
\text { shape }\end{array}$ & Nest composition \\
1 & Olea oleaster & 5.1 & 24 & 12.9 & 10.1 & Round & Dead leaves, twigs, rootlets, grasses \\
2 & Acacia nilotica & 5.5 & 23.6 & 13.1 & 9.8 & Round & Dead leaves, twigs, rootlets, grasses \\
3 & Acacia nilotica & 5.3 & 25.4 & 13.2 & 10.3 & Round & Dead leaves, twigs, rootlets, grasses \\
4 & Olea oleaster & 5.3 & 26.5 & 14 & 10.5 & Round & Dead leaves, twigs, rootlets, grasses \\
& & $5.3 \pm 0.16$ & $24.87 \pm 1.33$ & $13.3 \pm 0.48$ & $10.17 \pm 0.29$ & & \\
\hline
\end{tabular}


Table 6: Egg and Breeding ecology s of Grey Bush Chat at Sheikh Badin National Park.

\begin{tabular}{|c|c|c|c|c|c|c|c|c|c|}
\hline $\begin{array}{l}\text { Nest } \\
\text { No. }\end{array}$ & $\begin{array}{l}\text { Clutch size } \\
\text { (Eggs) }\end{array}$ & $\begin{array}{l}\text { Weight of } \\
\text { egg (g) }\end{array}$ & $\begin{array}{l}\text { Length of } \\
\text { egg }(\mathrm{mm})\end{array}$ & $\begin{array}{l}\text { Width of } \\
\text { egg }(\mathrm{mm})\end{array}$ & $\begin{array}{l}\text { Volume of } \\
\operatorname{egg}(\mathrm{cm} 3)\end{array}$ & Color of egg & $\begin{array}{l}\text { Incubation } \\
\text { period (Days) }\end{array}$ & $\begin{array}{l}\text { Hatching } \\
\text { success }\end{array}$ & $\begin{array}{l}\text { Fledging } \\
\text { success (\%) }\end{array}$ \\
\hline \multirow[t]{2}{*}{1} & \multirow[t]{2}{*}{2} & 5.7 & 21 & 15.3 & 2.502188 & \multirow{2}{*}{$\begin{array}{l}\text { Turkish blue with } \\
\text { black dotes }\end{array}$} & \multirow[t]{2}{*}{14} & \multirow[t]{2}{*}{100} & \multirow[t]{2}{*}{100} \\
\hline & & 5.9 & 20.1 & 17.3 & 3.0620061 & & & & \\
\hline \multirow[t]{3}{*}{2} & \multirow[t]{3}{*}{3} & 4.9 & 20.8 & 14.8 & 2.3190203 & \multirow{3}{*}{$\begin{array}{l}\text { Turkish blue with } \\
\text { black dotes }\end{array}$} & \multirow[t]{3}{*}{12} & \multirow[t]{3}{*}{100} & \multirow[t]{3}{*}{100} \\
\hline & & 5.6 & 19.9 & 16 & 2.5930496 & & & & \\
\hline & & 5.3 & 20 & 15.7 & 2.5092682 & & & & \\
\hline \multirow[t]{2}{*}{3} & \multirow[t]{2}{*}{2} & 5.5 & 18.8 & 16.9 & 2.7330592 & \multirow{2}{*}{$\begin{array}{l}\text { Turkish blue with } \\
\text { black dotes }\end{array}$} & \multirow[t]{2}{*}{12} & \multirow[t]{2}{*}{100} & \multirow[t]{2}{*}{50} \\
\hline & & 5.6 & 19.3 & 15.9 & 2.4835296 & & & & \\
\hline \multirow[t]{4}{*}{4} & \multirow[t]{3}{*}{3} & 5.9 & 21.6 & 16.8 & 3.1030595 & \multirow{3}{*}{$\begin{array}{l}\text { Turkish blue with } \\
\text { black dotes }\end{array}$} & \multirow[t]{3}{*}{15} & \multirow[t]{3}{*}{100} & \multirow[t]{3}{*}{100} \\
\hline & & 4.8 & 20.1 & 14.2 & 2.0629587 & & & & \\
\hline & & 5.2 & 18.3 & 14.5 & 1.9584157 & & & & \\
\hline & $2.5 \pm 0.57$ & $5.44 \pm 0.38$ & $19.99 \pm 1.0$ & $15.74 \pm 1.05$ & $2.53 \pm 0.37$ & & $13.25 \pm 1.5$ & $100 \%$ & $87.50 \%$ \\
\hline
\end{tabular}

actively guard their territories against possible predation. The parent birds determine either to protect the nest after locating a danger near the nest (Lima, 2009; Klvaňová et al., 2011). To evade predation, the nest should have all the primary as well as secondary qualities needed for a bird's endurance, but it has to be almost unapproachable to the possible predators; as a consequence, the nest might be camouflaged or concealed, and during the process of nest-building birds mostly use grass stem and different leaves for temperature management (Hartman and Oring, 2003). Birds are peculiar about selecting the materials for nest building, and care and attention are provided to their nest building (Pettingill, 1985).

Our results indicated that the breeding season of Red-vented Bulbul starts from April to August, but breeding activities were found maximum during June, July, and August. Earlier studies have found that breeding time varies from place to place in different species. Such as Prajapati et al. (2011) reported that Red-vented bulbul starts their breeding activities from April to September, but they were most active from August to September in Balaram-Ambaji Wildlife Sanctuary Gujarat. Our findings are also consistent with an earlier study by Lamba (1968), which indicated that Red-vented bulbul's nests were constructed with metal wires, twigs, grasses, roots, and dead leaves. The color of the eggs of Red-vented bulbul was pale pink with clear large, irregular red-brown marks which are thicker at the broad end (Jerdon, 1863). Red-vented bulbul clutch size in the study area was slightly smaller than found by earlier studies (Ali and Ripley, 1971; Manju and Sharma, 2013; Prajapati et al., 2011; Rao et al., 2013). Watling (1983) reported that the average clutch size for Red-vented bulbul was 2.5 in Fiji. Similarly, Zia et al. (2013) found that the mean clutch size was 2.5 , ranging from $1-4$. These differences in clutch size among studies could be due to the food availability for offsprings near the nesting sites, as the larger clutch size was observed with the abundance of food availability (Vijayan, 1980). The average egg length and breadth found in our study were slightly smaller than an earlier study by Prajapati et al. (2011). Moreover, Rao et al. (2013) observed smaller egg length and width in Sikar Region for Red-vented bulbul compared to our findings.

In the current study, eight nests of the Baya-weaver bird were measured. They preferred mostly Cortaderia selloana, Acacia Nilotica, and Ziziphus mauritiana tree species for nesting. Another study nests of weaver Bird Ploceus philippinus was recorded at Acacia nilotica (Tariq et al., 2018). The average nest size and nest diameter recorded in the current study are closely related to the findings of earlier study conduct by Tariq et al. (2018). The Pale cream with dotes and light cream was observed in the study. In our study, the nests were round in shape and constructed from dead leaves, twigs, rootlets, and grasses. Similar results were observed by Tariq et al. (2018), where all nests were pendulum shaped and were made of grass branches and leaves.

The present study indicated that the breeding season of the Grey bush chat starts from May to August, with peak breeding activities being highest in June, July, and August. Both males and females 
were observed during the construction of nest on Olea oleaster and Acacia Niloticatrees. The Average Nest height $5.05 \pm 0.49 \mathrm{~m}$, mean nest diameter measured $24.3 \pm 1.54 \mathrm{~cm}$, Cup Diameter $13.08 \pm 0.61 \mathrm{~cm}$, and Cup Depth $\mathrm{cm} 10 \pm 0.41$. In the current study, the average egg weight $5.44 \pm 0.38 \mathrm{~g}$, Length of Egg $19.99 \pm 1.0 \mathrm{~mm}$, Width of Egg 15.74 \pm 1.05 . We found smaller sizes of eggs than the previous study by Ala-Eddine (2018) where Rufous Bush Chats egg size, length, breadth and volume were $2.79 \pm 0.02 \mathrm{~g}, 21.57 \pm 0.06$ $\mathrm{mm}, 15.7 \pm 0.04 \mathrm{~mm}$, and $2.73 \pm 0.02 \mathrm{~cm}^{3}$, respectively. Nest was Round in shape and constructed from dead leaves, twigs, rootlets, grasses. The color of the Grey bush chat was Turkish blue with black dotes.

\section{Conclusions and Recommendations}

We concluded that most bird species at SBNP Dera Ismail Khan, Pakistan utilizing the different plant/ tree species for their nesting and breeding activates like nest height, clutch size, hatching size, incubation period, and fledging success.

\section{Acknowledgements}

We are very thankful to Miss Zarnab Gul (BS Botany), Luqman Amin (BS Zoology), and Raheem Ullah (BS Zoology) for their help during data collection and compiling the data of the conducted study.

\section{Novelty Statement}

This work is conducted first time at SBNP and we found that how the birds species using the different trees for nesting.

\section{Author's Contribution}

WU Qing-Ming is the supervisor and planned the work. Inam ullah carried out fieldwork and collected the data. Ruqia Bibi' Najam Un Nisa analyzed the data and prepared the results and wrote the manuscript with the Help of WU Qing-Ming and inam ullah.

\section{Conflict of interest}

The authors have declared is no conflict of interest.

\section{References}

Ala-Eddine, A.B., Rabie, T., Mohamed, K.B., Mohamed, L.O., Michał, G. and Jerzy, B., 2018.
Egg size and shape variation in Rufous Bush Chats Cercotrichasgalactotes breeding in date palm plantations: Hatching success increases with egg elongation. Avian Biology Research, 11(2): 100-107. https://doi.org/10.3184/17581 5618X1520281116334

Ali, S. and Ripley, S.D., 1971. Hand Book of the Birds of India and Pakistan. Vol. 6. Oxford University Press, Bombay.

Birchard, G.F. and Deeming, D.C., 2015. Egg allometry: Influences of phylogeny and altricialprecocial continuum. In: Deeming, D. C., and Reynolds, S. J., (eds). Oxford University Press, Oxford. Nests, eggs and incubation: New ideas about avian reproduction, pp. 97-112. https://doi.org/10.1093/ acprof:oso/9780198718666.003.0009

Connell, J.H., 1975. Some mechanisms producing structure in natural communities. In: Cody, M.L. and Diamond, J.M., (eds). Ecology and Evolution of Communities, pp. 460-490.

Donald, F.H., 1979. Practical methods of estimating volume and fresh weight of bird eggs. Auk, 96:73-77

Diamond, J.M., 1978. Niche shifts and the rediscovery of inter-specific competition. Am. Sci., 66: 322-331.

Gokula, V. and Vijayan, L., 2001. Nest site characteristics of spotted munia (Loncura punctada) in madumalai wildlife sanctuary. Southern Indian journal of South Asian Natural History, 5: 187-190. https://doi. org/10.3161/068.036.0107

Hartman,C.A. and Oring,L.W.,2003.Orientation and microclimate of horned lark nests: The importance of shade. Condor, 105: 158-163. https://doi.org/10.1093/condor/105.1.158

Holway, D.A., 1991. Nest site selection and the importance of nest concealment in the Black Throated Blue Warbler. Condor, 93: 575-581. https://doi.org/10.2307/1368189

Jerdon, T.C., 1863. The Bird of India, 1(2): 93-96.

Kern, M.D. and Riper, C., 1984. Altitudinal variation in the Hawaiian honeycreeper Hemignatus virens virens. Condor, 86: 443-454. https://doi.org/10.2307/1366825

Klvaňová, A., Hořáková, D. and Exnerová, A., 2011. Nest defense intensity in House Sparrows Passer domesticus in relation to parental quality and brood value. Acta Ornithol., 46: 47-54. https://doi.org/10.3161/000164511X589910 
Krist, M., 2011. Egg size and offspring quality: A meta-analysis in birds. Biol. Rev., 86: 692-716. https://doi.org/10.1111/j.1469185X.2010.00166.x

Lack, D., 1968. Ecological adaptations for breeding in birds. Methuen, London.

Lamba, B.S., 1968. Wire notes of Red-vented bulbul (P. cafer). Journal of the Bombay Natural History and Society, 68: 222.

Lee, J. K. and Lima, S.L., 2017. Egg viability as a determinant of clutch size in birds: A basic analysis.Avian Biol.Res.,10:98-106.https://doi. org/10.3184/175815617X14878495604562

Lenington, S., 1980. Female choice and polygyny in Red Winged Blackbirds. Animal Behavior, 28: 347-361. https://doi.org/10.1016/S00033472(80)80043-1

Lima, S.L., 2009. Predators and the breeding bird: behavioural and reproductive flexibility under the risk of predation. Biol. Rev., 84: 485-513. https://doi.org/10.1111/j.1469185X.2009.00085.x

MacArthur, R.A., 1972. Geographical ecology: Patterns in the distribution of species. Harper and Row, New York.

Manju, S. and Sharma, R.K., 2013. Breeding biology of red-vented bulbul (Pycnonotus cafer). International Journal of Zoology and Research, 3(5): 1-4.

Martin, P.R. and Martin, T.E., 2001. Ecological and fitness consequences of species coexistence: A removal experiment with Wood Warblers. Ecology, 82: 189-206. https://doi. org/10.1890/0012-9658(2001)082[0189:EAF $\mathrm{COS}] 2.0 . \mathrm{CO} ; 2$

Martin, T.E. and Roper, J.J., 1988. Nest predation and nest- site selection of a western population of the Hermit Thrush. Condor, 90: 51-57. https://doi.org/10.2307/1368432

Nalwanga, D., Lloyd, P.M., Du Plessis, A. and Martin, T.E., 2004. Nest-site partitioning in a stranded shrub land bird community. The Ostrich, 75(4): 250-258. https://doi. org/10.2989/00306520409485452

Newton, I., 1989. Lifetime reproduction in birds. Academic Press, San Diego.

Pandey, D.N. and Mohan, D., 1993. Nest site selection by cavity-nesting birds on Melia azedarach L. and management of multiple use forests. Journal of Bombay Natural History Society, 90: 58-61.
Parejo, D., Avilés, J.M. and Rodríguez, J., 2012. Supplemental food affects egg size but not hatching asynchrony in rollers. Behav. Ecol. Sociobiol., 66: 1097-1105. https://doi. org/10.1007/s00265-012-1360-1

Perrins, C.M., 1996. Eggs, egg formation and the timing of breeding. Integrated Botanical Information System, 138: 2-15. https://doi. org/10.1111/j.1474-919X.1996.tb04308.x

Pettingill, O.S., 1985. Ornithology in laboratory and field, Fifth ed. Academic Press, New York, NY.1985

Pilz, K.M., Smith, H.G., Sandell, M. and Schwabl, H., 2003. Inter female variation in egg yolk androgen allocation in the European Starling: do high quality females invest more? Anim. Behav., 65: 841-850. https://doi.org/10.1006/ anbe.2003.2094

Prajapati, S.H., Patel, C.D., Parmar, R.V. and Patel, M.I., 2011. Breeding performance of Redvented Bulbul (Pycnonotus cafer). Life Sciences Leaflets, 11: 298-304.

Quinn, J.L., Prop, J., Kokorev, Y. and Black, J.M., 2003. Predator protection or similar habitat selection in red-breasted goose nesting associations: extremes along a continuum. Anim. Behav., 65: 297- 307. https://doi.org/10.1006/ anbe. 2003.2063

Rader, M.J., Brennan, L.A., Hernàdez, F., Silvy, N.J. and Uwu, B., 2007. Nest-site selection and nest survival of northern Bobwhite of southern Texas. Wilson Journal of Ornithology, 119: 392399. https://doi.org/10.1676/06-069.1

Randall, P., Moore and Robinson, W.D., 2004. Artificial bird nests, external validity, and bias in ecological field studies. Ecology, 85(6): 15621567.

Rao, M.S., Ojha, P.R. and Rao, R., 2013. Breeding Performance of Red-vented Bulbul(Pycnonotus cafer) in Sikar Region (Rajasthan) India. International Journal of Science and Research, 2(7): 319-322.

Reitsma, L.R. and Whelan, C.J., 1999. Does vertical partitioning of nest site decrease nest predation. Auk, 117: 409-415. https://doi. org/10.1093/auk/117.2.409

Slagsvold, T., 1982. Clutch size, nest size, and hatching asynchrony in birds: Experiments with the ${ }^{\circledR}$ eldfare (Turdus pilaris). Ecology, 63: 1389-1399. https://doi.org/10.2307/1938866

Slagsvold, T., 1989a. On the evolution of clutch size 
and nest size in passerine birds. Oecologia, 79: 300-305. https://doi.org/10.1007/BF00384308

Slagsvold, T., 1989b. Experiment on clutch size and nest size in passerine birds. Oecologia, 80: 297-302. https://doi.org/10.1007/BF00379030

Sockman, K.W., 2016. The regulation of behavioural plasticity by performance-based feedback and an experimental test with avian egg production. Am. Nat., 187: 564-575. https://doi.org/10.1086/685881

Steenhof, K., and Newton, I., 2007. Assessing nesting success and productivity. In: Raptor research and management techniques. D.M. Bird, and K.L.Bildstein,Hancock House,Surrey, British Columbia, Canada and WA Blaine, U.S.A. D.M. Bird, and K.L. Bildstein[Eds.] pp. 181-192.

Tariq, M., Syed, W.A.S., Muhammad, R., Hira, F., Faraz, A. and Muhammad, S.N., 2018. Nesting Use of Tree Species by Avifauna Inhabiting Pabbi Range Forest, Kharian, Punjab, Pakistan.
Pakistan J. Zool, 50(1): 329-338. https://doi. org/10.17582/journal.pjz/2018.50.1.329.338

Vijayan, V.S., 1980. Breeding biology of bulbuls, pycnonotus cafer and pycnonotus luteolus luteolus (Class: Aves, Family: Pycnonotidae) with special reference to their ecological isolation.

Vyas, B.M., 2009. Breeding seasons and nest site selection of some selected urban birds of Visnagar city area and its vicinity. Asian Journal Animal Science, June to November, 4(1).

Watling, D., 1983. The breeding biology of the Red-vented Bulbul Pycnonotus cafer in Fiji. Economic and Monetary Union, 83(3): 173-180. https://doi.org/10.1071/MU9830173

Zia, U., Ansari, M.S., Akhter, S. and Rakha, B.A., 2013. Breeding Biology of Red Vented Bulbul (Pycnonotus cafer) in the area of Rawalpindi/ Islamabad. Journal of Animal and Plant Sciences, 24(2): 656-659. 